\title{
Internationalizing Penn State Law: Strategy, Leadership and Faculty
}

\author{
Zhailagul Sagyndykova ${ }^{1} \&$ Su Jin Hong ${ }^{1}$ \\ ${ }^{1}$ Penn State Law, PA, USA \\ Correspondence: Zhailagul Sagyndykova, Visiting scholar at Penn State Law, PA 16802, USA.
}

Received: October 23, 2015

Accepted: January 26, $2016 \quad$ Online Published: February 19, 2016

doi:10.5430/irhe.v1n1p153

URL: http://dx.doi.org/10.5430/irhe.v1n1p153

\begin{abstract}
This is a short overview of how an American law school can brainstorm strategies for internationalizing American legal education, form a group of leadership, empower relevant faculty and staff, and implement those internationalization strategies with clear goals in mind such as enlarging the cohort of international students and increasing the amount of international research of the law faculty. The effectiveness of the internationalization strategy of the particular American law school confirmed by survey data and supported by the large numbers of highly qualified lawyers in the master's program for international lawyers (LL.M. program) and their positive feedback. The long term and proactive strategy, highly qualified and experienced leadership, outstanding and approachable faculty became the substantial mechanisms and determinants to raise the school's international profile.
\end{abstract}

Keywords: internationalization, survey, strategy, leadership, international faculty

\section{Introduction}

Kazakh visiting scholar and professor of a leading American Law school, i.e., Penn State Dickinson School of Law (hereinafter "Penn State Law") put forward the intention to observe, analyze, and evaluate Penn State Law in terms of internationalization of American legal education and thus, get insight from the actual working process of the Graduate and International office of the Law School. The Graduate and International Programs' staff and faculty members (hereinafter referred to as "the International Team") are responsible for overseeing and supporting the Penn State Law's international engagement with respect to the international programs. We would like to give special thanks to Professor Tiffany Bennett who encouraged us throughout the writing process and provided valuable inputs in terms of organization and grammar of the writing.

This paper will touch upon the following questions: What are some of the benefits and challenges in internationalizing the Law school? What are the methodologies and instruments to implement the internationalization of the U.S. legal education?

The main scope of the research is to observe, describe and analyze the profitable experience in internationalizing the law school; however, identifying the challenges encountered in the internationalization process can be of equal value. Interpretation of the Law School strategy to 2020 and the Internationalization strategy, consideration of the International office in the fulfillment of its unique role and the polling of international students were the general tasks of the research. The intention of this article is to provide recommendations for Kazakhstani universities and the Kazakh government when it comes to Kazakh internationalization of Higher Education. The uniqueness of this research is based upon the observations and assessments of the effective implementation of the international strategy from the perspective of an outsider of the law school, visiting the institution as a research scholar and a professor, who is involved in the day-to-day operation of the International Team.

Consequently, the relevance of the paper coincides with the consistent research in the sphere of the legal education the U.S. Law schools, its transformation to globalization. Therefore, evolutionary and transformatory shifts in legal education, its globalization and internationalization are the crucial and important themes of discussion. For instance, John Sexton foresaw the essential changes in the composition of the legal education. The scholar highlights the paramount trend as globalization that converges with legal education. "Since our graduates will practice in a globalized world, they will have to know how the reality of globalization affects the way legal rules operate, and they must develop a set of techniques for mediating within a much more complex sovereign system." Sexton draws the curriculum, which will produce the lawyer/leader who is the object of American legal education; hence the phenomenon of globalization and global perspectives will be infused in the course of study (Sexton, 2000). 
Farida Ali in the paper "Globalizing the U.S. Law School Curriculum: How should Legal Educators respond?" emphasizes legal practice, law students and law school curricula in the global context. Global economic markets and the new trends at the international level create new opportunities and challenges for the legal profession. Advancements imply that lawyers must acquire basic knowledge of international law and regulatory systems in their practice to augment the success and diminish the detriments of the globalization for their clients. Thus, it means that law schools should reform legal education to meet the challenges and opportunities of the current global legal market (Ali, 2013).

Additional research on the evolution of legal education demonstrates the effect of the relevance of the current topic of discussion. Simon Chesterman studies the transformation of the legal education through three paradigms "international", "transnational" and "global" which moving forward leave some things stable but many others will change. The author supposes that the global market will push more states to move in the direction of American - style J.D. graduate law degree. Globalization sees "the world as a web in the diverse and various ways, with lawyers needing to be comfortable in multiple jurisdictions" (Chesterman, 2007).

Claudio Grossman expresses her opinion on the law school curriculum. She mentions that the curriculum should be designed in an emerging transnational legal order in order to establish a transparent and proactive legal education that integrate into the wider world which allow graduate law students to get employed and achieve brilliant legal careers (Grossman, 2000).

The International Team of Penn State Law is responsible for recruiting international lawyers for the school's graduate programs, designing program elements to support and provide language support for international students enrolled in academic programs. Penn State Law prioritizes diversity in professionalism and experience educating a diverse group of students, working with international faculty and staff with diverse backgrounds. "We will recruit highly qualified and diverse students, faculty, and staff, and maintain our international graduate law program, which currently includes students from over 25 countries" (Unit Strategic plan: Penn State Law, 2014).

The uniqueness of the research is found in its attempt to analyze both internally and externally the implementation of the strategic plan. In doing so, best practices for implementation are identified.

\section{Definition of Internationalization of Higher Education}

Different scholars interpret the definition of internationalization of Higher education at different scopes. One ad hoc definition given by J.Knight is "Internationalization is the process of integrating an international, intercultural or global dimension into the purpose, functions or delivery of post-secondary education" [Knight, 2004). Knight commented further that countries and institutions can have a common comprehension of the definition of internationalization, even though the fulfillment of internationalization depends on cultural, historical, political issues and the priorities and resources obtain by each (Hans de Wit, 2013).

Time flies, technology changes, relations and collaborations transcend, and higher education transforms, and integrates into global education. These factors caused the evolution of the definition of internationalization with the tendency to rethink and remodel it. De Wit defines "Internationalisation as a process to introduce intercultural, international and global dimensions in higher education to improve the goals, functions and delivery of higher education, and with that to improve the quality of education and research". Worth noting that De Wit recognized internationalization not as a goal in itself, but as a tool for the quality improvement and research enhancement grounding the higher education and its integration into internationalization (Hudzik, 2013).

John Hudzik describes internationalization as comprehensive one, which he defined as, commitment and action to integrate international, global and comparative perspective throughout the teaching, research and service missions of higher education, achieving benefits in core learning and discovery outcomes, and becoming an institutional imperative not just a desirable possibility (Hudzik, 2013). Internationalization acquired its obligations and commitments to the students' society, academia and international partners.

These approaches to the notion of internationalization suppose that it constantly evolves and matures because internationalization of higher education replaced in 1990s international education and now expands to the globalized dimensions, updating its instruments and actions. It is significant for the research to give a right definition to the notion of internationalization of higher education.

Professors Altbach and Knight discern the definitions of globalization and internationalization, where "globalization may be unalterable, but internationalization involves many choices. Globalization tends to concentrate wealth, knowledge, and power in those already possessing these elements while internationalization is a two-way 
street—students move largely from south to north, and serves important needs in the developing world (Altbach, Knight, 2007).

Going back to J. Knight, she defines the internationalization as a specific process for various regions, nations and institutions. Penn State Law determines internationalization as integration by means of research, legal education and service to the state, country and global society, contributing to the resolution of international problems and preparing a diverse student body (Knight, 2011).

\section{Purpose of the Current Study}

John K.Hudzik described metaphorically internationalisation as a road without end. It constantly draws and affects higher education pushing to a persistent evolution of challenges and opportunities in global society. Adding that, "Internationalisation is challenging for any institution, but laden with myriad of opportunities." (Hudzik, 2013). As the study evolved, greater emphasis was placed on the methods used by the school to both raise its international profile and respond to the unique challenges raised by the internationalization of legal education.

What are opportunities of international education development for the school? What are challenges in internationalizing of higher education?

In order to find the answers to these questions, we did not take any attempts to investigate and reveal any impediments that could disfavor the faculty. As mentioned earlier, the results of the research will be utilized for international activity development in Kazakhstani education sphere.

\section{The Object of the Research}

Founded in 1834 by Judge John Reed, The Dickinson School of Law is the oldest law school in Pennsylvania and the fifth oldest in the nation. In 2000, the Law School merged with Penn State. In the summer of 2014, Penn State received approval from the American Bar Association to operate the two campuses as two distinct Penn State law schools, both of which share the history and achievement of The Dickinson School of Law. The one located in University Park, main campus of the Penn State University, is called "Penn State Law" and the other school which is located in Carlisle is called "Dickinson Law".

Throughout its 40 year history of offering the LL.M. program, both law schools welcomed students from around the world. Currently, as of the academic year of 2014-2015, Penn State Law hosted approximately 80 students from 25 countries around the world.

\section{Methods}

This paper is intended to analyze the process of internationalization by investigating and examining various participants and stakeholders. In order to identify strengths and weaknesses of the law school's internationalization strategy and its implementation, this article utilized questionnaires developed by Penn State Law marketing department with adjustments to the research. In addition, as an effort to reveal the international collaboration in research, 50 LLM students (Master in Law) were interviewed and questioned as well as 10 SJD (Doctor's degree in Law) international students and 5 members of the staff.

Apart from the strategy, it was essential to conduct a survey to navigate strengths and weaknesses of the LLM program for international students and integrate the result of the survey with this research paper. The survey was a scientifically based research and conducted anonymously andv50 LLM students representing 15 countries responded to the survey. Survey respondents were predominately male (by 68\%), which is common for surveys among international students (Hunter) The average age of the respondent was 25 years. 32\% of respondents come from China, while $12 \%$ of respondents originate from Saudi Arabia as well as 12\% from Norway. This type of pattern in terms of dominating number of Chinese and Saudi Arabian students often occurs at other universities worldwide. $12 \%$ students from Norway resulted from the Law school's consistent and solid collaboration with Oslo and Bergen Universities in Norway. The rest of students come from a number of other countries including: Brazil, France, India, Iraq, Italy, Kazakhstan, Kuwait, Liberia, Nigeria, South Africa, Turkey, and the UAE.

The results of the survey in terms of English language proficiency demonstrated that most of the students had Upper-Intermediate Level (72\%) which is consistent with the requirements for admission to the Program. A balance existed between how the respondents learned about the school: friends and relatives (30\%), website (24\%), and the other part of respondents gave their own answers underlining collaboration (16\%) and sponsorship (8\%). Thus, the "word of mouth" approach to exchanging information about the university takes a leading position; however, online social media platforms are not far behind. 
These results show how remarkable achievement the law school can be in case it enhances collaboration with strategic partners (China, Italy, Norway, etc.) around the world to attain the goal of internationalization.

\section{Determinants of a Law School: Strategy}

"While there is no one model that fits all, any comprehensive, integrated approach to internationalisation will require appropriate strategy, structures and support."(Hunter). In this globalized world, many institutions try to make efforts to internationalize institutions, design strategies, change from reactive to proactive structures and evolve short term schemes into long-term actions. Academic institutions that create well-planned, long-term, and organized strategies aimed at fulfilling the internationalization goals and tasks. Strategy is the preferred term because of the inherent notion of planned direction and the fact that it can be applied to academic types of activities as well as organizational types of procedures and policies (Knight, 1999). De Wit underlines that an internationalisation strategy vary from a teacher-training programme to a school of dentistry or a business school. In addition, different levels of education can obtain different internationalisation strategies (Hans de Wit, 2013).

In correspondence with new challenges and trends, Penn State Law has its own living document "Strategic plan for Law School 2015-2020" including a robust internationalization plan. The School aims to educate a diverse group of highly credentialed domestic and international students with legal professional skills and maintain a diverse faculty well versed in transformational research and teaching (Unit Strategic plan: Penn State Law, 2014). The Internationalization strategy of the school fosters the diversity of international cohort of students. The strategy declares that the School will recruit knowledgeable and diverse students, faculty, and staff, and emphasizes the increasing importance of the international graduate law programs, which educate students from over 25 countries (Unit Strategic plan: Penn State Law, 2014).

Fiona Hunter focuses on a thorough financial plan installed in the implementation of the strategy to invest in the human resource, infrastructure and organization. "If the new direction takes the university beyond its current capacity, it will most likely imply a change in financial strategy that identifies new income streams and develops a more diversified funding base" (Hunter]. At the present stage, the Law School established a well-balanced international office composed of an Assistant Dean of Graduate and International Programs, Director of Graduate and International programs, a research scholar, LLM Admission Specialist, 2 Adjunct professors of Legal Writing, 3 Applied Linguistics Graduate Teaching Assistants, 2 LLM program coordinators. Regarding the aspect of infrastructure and organization one of the strengths of the law school are the campus, facilities and library as $22 \%$ of the respondents pointed out.

In addition, the strategy of 2015-2020 highlights the administration's awareness and understanding of the future opportunities that regulate the groundwork for a new strategy of internationalization. While the juris doctor (JD) degree is the core mission of the school, the school also advances two international graduate law degree programs: Masters of Law (LL.M.) and Doctor of the Science of Law (S.J.D.). "These programs expand our reputation for excellence globally, expand the international cultural awareness of our students and faculty, and provide international students a superb education in U.S. law and legal systems" (Unit Strategic plan: Penn State Law, 2014).

In Europe, Fiona Hunter acknowledges the Bologna Process impact as a vehicle that engineers internal comprehension of international ambition and administers a strategic course calling it "external change became internal change". [Hunter, 2013). In the Law School, professor Larry Cata Backer affirms that the priorities of a stockholder evolve and the law school's employer base changes. The law school admits the past, resides in the present and at last it should predict the future with envision of the stockholder's desires and options (Backer, 2008).

The Law School foresees a strategy that would engage to be one of the country's best law schools, enhancing law around the world and transforming lives through legal education. Yet, there is no indication of American students' involvement in study abroad process, which could foster their employability and enrich their skillsets in global learning and global society. A Global society requires multilingual lawyers with highly qualified legal credentials in international litigation and arbitration to handle international issues.

The strategy of the Law School will be enforced until 2020 and will be implemented by the International Team under the school's leadership.

Summing up, the strategy of the school is vitally significant mechanism for the productivity of internationalization.

\section{Leadership}

If the strategy is the instrument for coordination and orientation of the internationalization, the leadership is the flagman of realization.

In regards to the internationalization of Korean higher education is the need to survive the higher education competition through internationalization, accordingly, in the implementation of internationalization, the leader's role is 
mentioned as a primary factor. Thus, the universities tend to appoint administrators from the faculty members on a rotating basis (Kim, 2010).

We conclude that the internationalization strategy and its successful implementation are completely built upon the internationalization leadership. The number of participants and sessions on Internationalization Leadership at AIEA (Association of International Education Administrators) and NAFSA (National Association of Foreign Student Advisers): Association of International Educators conferences in 2015 show the increasing importance of highly qualified Senior International Officer (SIO) experience, who can be either a vice provost or an associate dean (Note 1). The AIEA issues an annual survey on senior international education officers, their institutions and offices. The result of the 2014 survey reveals the general position, responsibilities and the SIO's experience in the US Higher education institutions. It demonstrated that most of the respondents consider SIO position as essential, distinguished, and consistent at higher education institutions, with an accent to student recruitment and human resource workforce preparation. The SIO position is relatively new, because $60 \%$ of the respondents have held the positions less than 5 years. The number of workshops and seminars devoted to the SIO's responsibilities reflects the wide range of authority and importance of their leadership in the area of internationalization development at the institution. For instance, out of 102 workshops, 23 were dedicated to the enhancement of the SIO capabilities in leadership change. The 2015 AIEA conference provided topics on the SIO's role in international students' life, changing admission practices, global leadership realities, development of strategic plans, internationalization of curriculum, research, advancing the comprehensive approach and paradigm of the SIO position and its responsibilities, ethics issues and impact, strategic issues, global and transnational education, women leadership and characterizing the SIO career landscape.

The responsibilities that SIO demonstrated in the survey overlap with the AIEA workshops, commenting that some valued characteristics of an SIO are: profound knowledge of world affairs, business principles and practices and cross-cultural communication methods. Paramount and meaningful skills of an SIO also included, among others, interpersonal skills (68\%), followed by planning/visioning skills (65\%) and intercultural competence (55\%) (Note 2). The survey and personal observation confirmed the ever increasing importance of a SIO and its team's role that can enforce the integration of the internationalized faculty to a globalized society.

The Law school initiated the position of an associate dean in 2012 when the school commenced its internationalization at a full swing. The SIO at the Law school is a chief manager with legal education of JD or an equivalent, who is a member of the law school's senior leadership team, reporting directly to the Dean of the law school and playing a critical role in shaping the law school's overall strategic direction. Responsibilities include: LL.M. and S.J.D. program leadership, management, and oversight; recruiting and advising international students; negotiating agreements with global partner institutions, expanding post-graduation opportunities for students, helping expand the law school's worldwide distance education program and teaching courses in U.S. law and legal systems to international students. The professional requirements include international legal professional experience, the ability to interact with a diverse group of individuals from different countries and cultures and the ability to travel globally in furtherance of law school programs (Note 3).

There are two crucial skills for the Law School SIO. First, the SIO must possess excellent legal writing skills and outstanding interpersonal skills. Additionally, SIO must be bilingual even more trilingual with experience living and working abroad.

Regardless of responsibilities, personal skills and qualities, the position of SIO should preferably be stable and extended in order to create a balanced and incessant integration into the global world.

The Law school experienced two leaves of the associate deans during 2 years, which did not mirror the entire work productivity of the graduate and international programs but partially influenced the team's morale.

In Kazakh Universities, the leadership presented by the joint positions of the Vice-rector on International Affairs and research or academic affairs which generally does not reflect positively on the internationalization implementation, exacerbated by the lack of foreign language proficiency of the leadership.

The SIO in the International office is a leader who facilitates the team, raises the international profile of the school and implements the strategic objectives innovatively and creatively leading the Law school to its accomplishments.

\section{International Faculty}

$34 \%$ of LLM students and $100 \%$ of the interviewed SJD students pointed out the professionalism of academic staff of Penn State Law and its high quality. The scholars agree on the point that cooperative faculty is a vital and key element in internationalization strategy fulfillment (Croom, 2012; Pandit; Backer). 
The International faculty's awareness and willingness to internationalize and collaborate is a crucial factor in successful performance, because not every law school can present itself as a leader in this area (Backer). Professor Altbach highlights the humanitarian field as preferably national one, however with some foreign influence in tools and mechanisms to research (Altbach, 2014).

The Law school's international faculty in conjunction with School of International Affairs maintains the mission. The respondents stress that the faculty provides a great amount of language support, which is very important for international students' success as well as the possibility to interact with well-known professors and American JD students. The ability to have positive interactions with law faculty and American JD students on a regular basis is the hallmark of successful internationalization of legal education. Helping the law faculty to have full comprehension and awareness of how the school will benefit from internationalization outcomes to achieve the internationalization of the programs at the law school.

A group of scholars conducted a research with a request to students, faculty and staff of what internationalization meant to them. The results showed that $32 \%$ of faculty, $46 \%$ of students and $17 \%$ of staff did not respond and many respondents commented as follows: "I am not sure", "sounds like", "it's a guess", etc. Apparently, the research group neither understood the meaning of the concept nor envisioned the internationalization as sustainable and beneficial method of disseminating education. Yet, interestingly enough, the respondents $(96 \%$ of surveyed faculty and $82 \%$ of students) acknowledged instinctively that the faculty should reinforce "internationalization in its policies and plans" (Roumiana Ilieva, Kumari Beck, Bonnie Waterstone, 2014).

The faculty at Law school quite positively assesses internationalization as a commitment to the international students and collaboration. The strategy of the school is of an evidence. "In addition, continue to pursue an appropriate balance between faculty commitment to supervision of S.J.D. students and other research, teaching, and service opportunities." (Unit Strategic plan: Penn State Law, 2014).

To achieve a harmonious balance between different parts of the university is not an easy task; however, they understand that the success of the departments is fully built upon both benevolent working climate and mutual trust (Hunter, 2013).

The international faculty encompasses outstanding, prominent and foremost specialists and professors in law and policy with great experience in research and teaching abroad. Many are fluent in other languages such as Spanish, Russian, Italian and Chinese and are proficient in comprehensive legal writing and exhibit the interpersonal and intercultural capabilities needed to negotiate and communicate with international partners, international students and visiting scholars.

Diversity in curriculum, consistency in strategic relations, commitments to the students and international faculty, and promote the uniqueness of the Law school and SIA would stimulate and foster the integration of the Law school to global education space.

\section{Successful Implementation of the Internationalization: Strategy, Leadership and Faculty}

The abovementioned analysis of the Law school's accomplishments in internationalization resulted in the drawing a triangle of the basic determinants in establishing long term and proactive relationships. The triangle symbolizes the interconnection of the three elements. The strategy prompts involvement into internationalization; the leadership manages and fulfills it and the faculty fosters collaboration. The core of the triangle is the rewarding and favorable climate for internationalization. The strategy and leadership are the determinants that could not exist separately from the faculty because the faculty is the key element. At the same time, the faculty as a core element cannot be successful, sustainable and binding without a strategy and leadership.

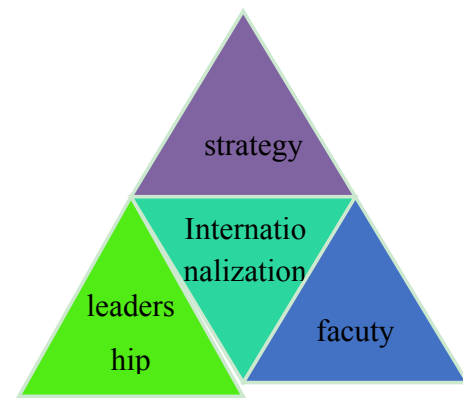




\section{Conclusion}

In conclusion, highlighting three determinants of internationalization favorable existence, i.e., strategy, leadership and faculty based on three sources of evidence, the Law school strategy for 2015-2020, the survey data and the personal consideration Penn State Law's achievement can be deemed as a successful example for conducting internationalization in higher education institution.

\section{References}

Boston College CIHE and GO Group. (2014). The rationale for sponsoring students to undertake international study: an assessment of national student mobility scholarship programmes. Study by British Council and the German Academic Exchange Service.

Claudio Grossman. (2000). Building the World Community: challenges for legal education. Dickinson Journal of International law, 18, 441.

Croom, P. (2012). Internationalization and Institutional Strategy. The International Journal of Higher Education and Democracy, 3, 99-11.

Eun Young Kim. (2010). Internationalization of Korean Higher Education. Dissertation, submitted in partial fulfillment of the requirements for the degree of Doctor of Philosophy in Educational Policy Studies in the Graduate College of the University of Illinois at Urbana-Champaign.

Farida Ali. (2013). Globalizing the U.S Law School Curriculum: How should legal educators respond? Juris Doctor, 2013, Northwestern University School of Law, pp. 249-282.

Fiona Hunter. (2013). Internationalization and Institutional responsiveness: harnessing the power of imagination. An Introduction to Higher Education Internationalization, CIHE, Universita cattolica del Sacro Cuore, Milan, Italy, pp. 61-75.

Hans de Wit (Ed.). (2013). An Introduction to Higher Education. Center for Higher Education Internationalization, Universita Cattolica Del Sacro Cuore, Milan.

John A. Sexton. (2000). Thinking about the training of lawyers in the next millennium. New York University School of Law, presented at the Queen Elizabeth II Conference Center, Churchill Auditorium on July 18.

John Hudzik. (2013). Changing paradigm and practice for higher education internationalization. CIHE, Universita cattolica del Sacro Cuore, Milan, Italy, pp. 57-59.

Kavita Pandit. (1999, October). Leading Internationalization. Annals of the Association of American Geographers State University of New York. Presidential Address, (4), 645-656.

Knight, J. (1999). Internationalization of Higher Education. Quality and Internationalization of Higher Education, Paris, OECD, 13-23

Knight, J. (2004). Internationalization Remodeled: Definition, Approaches, and Rationales. Journal of Studies in International Education. http://dx.doi.org/10.1177/1028315303260832

Knight, J. (2014). International Educational Hubs: Student, Talent, Knowledge-Innovation Models. Springer, 251.

Larry Cata Backer. (2008). Internationalizing the American Law School Curriculum (in Light of the Carnegie Foundation's Report). The Internationalization of law and Legal Education. The Netherlands: Springer Science + Business Media, pp. 49-128. http://dx.doi.org/10.1007/978-1-4020-9494-1_5

Philip G. Altbach. (2007). Globalization and the University: realities in an unequal world. International Handbook of Higher Education, Springer, 121-141.

Philip, G. Altbach, \& Jane Knight. (2007). The Internationalization of Higher Education: Motivations and Realities. Journal of Studies in International Education, 290-306.

Roumiana Ilieva, Kumari Beck, \& Bonnie Waterstone. (2014). Towards sustainable internationalization of higher education. Higher Education, Springer, 875-889. http://dx.doi.org/10.1007/s10734-014-9749-6

Simon Chesterman. (2007). The Evolution of Legal Education: Internationalization, Transnationalization, Globalization. Singapore, Singapore Journal of Legal Studies, 877-888.

Unit Strategic plan: Penn State Law; University Park, PA, 2014/2015 through 2018/2019.

\section{Notes}

Note 1. http://www.aieaworld.org/assets/docs/Surveys/sio\%20survey\%20summary.pdf

Note 2. http://www.aieaworld.org/assets/docs/Surveys/sio\%20survey\%20summary.pdf

Note 3. https://psu.jobs/job/56033 